\title{
Syntactic and semantic issues in sequences of the type (Adjective)-Noun-(Adjective)
}

MATILDE MIGUEL

AMÁLIA MENDES

\section{Abstract}

This paper focuses on some properties of agreement inside the Noun Phrase, especially in what concerns adjectives and "adjectival quantifiers", based on spoken corpora of Brazilian Portuguese and of the five African varieties of Portuguese (with special attention to the Santomean variety). We present the most salient patterns of defective agreement, focusing especially in number agreement, and contrast our findings across varieties. Results clearly differ in terms of the agreement found in the left and in the right periphery of the noun, as other studies already pointed out. The "specifiers" of the noun and pre-nominal adjectives tend to carry the plural morpheme, while the noun itself and post-nominal adjectives are defective in number marks. We put forward some possible issues for the interpretation of these data: the distinction made by speakers between the functional and the lexical domain; the relation between defective agreement on head nouns and cases of bare singular nouns which might be interpreted in these contexts as kind terms; and, finally, the fact that indefinite quantifiers may combine with these bare singulars.

\section{Introduction}

\subsection{The question ${ }^{1}$}

Based on spoken corpora of informal register from urban varieties of Brazilian (Nova Iguaçu), Angolan, Mozambican, Guinean, Cape-Verdean

\footnotetext{
${ }^{1}$ For an accurate and deep insight on variable agreement inside the Noun Phrase within a Variationist Sociolinguistics framework, see Brandão in this volume.
} 
and Santomean Portuguese, this paper will focus on some properties of agreement inside the Noun Phrase (NP) in the above varieties, aiming to understand where the varieties spoken in Africa, as they appear in our sample $^{2}$, stand and whether there are evidences for systematic and consistent occurrences of defective agreement ${ }^{3}$. The main goal of our work will be to focus on variable agreement patterns between pre-nominal and post-nominal adjectives and noun head, including a special class of quantifiers, the 'adjectival quantifiers' that stand at the frontier between quantification and adjectival modification, as well as standard adjectival constituents.

We will explore along this work possible hypotheses regarding the patterns of defective agreement: is the relative position regarding the noun head an important factor, namely in terms of the left and the right position? Are number agreement marks found solely on the left most element of the Noun Phrase? Do functional and lexical items show different agreement properties inside the Noun Phrase? Are defective contexts purely a morphological factor, or do we have to consider phonological aspects? Also, how do the different varieties considered here behave regarding the most significant patterns of defective agreement?

On purely descriptive grounds, the hypothesis we will put forward is that some speakers in these varieties clearly split apart the two domains inside NP: the functional domain, where grammatical number is morphologically encoded by the realization of plural morpheme [-s], and the lexical domain, lacking grammatical plural number morpheme, this pattern being more systematic and better represented in BP.

\subsection{The corpora}

Our study is based on the corpus of Nova Iguaçu (NIG), in the metropolitan area of Rio de Janeiro, in what concerns BP. This spoken corpus includes transcriptions of informal register by 18 informants, distributed by gender and covering three different age spans (18-35 years, 36-55 years and 56-75

\footnotetext{
${ }^{2}$ A reviewer rightly points that such an observation would disallow any kind of generalization about the data. Indeed, as we will see along the paper, we do think that the data of the spoken varieties in Africa are yet too scarce to allow reliable generalizations about any of these varieties.

${ }^{3}$ In what follows, terms as defective, partial or even variable agreement do not have any theoretical intent, they are a mere shortcut to quote that the plural morpheme [-s] does not show up in all the internal constituents of the NP it is expected to be realized in Portuguese, in prescriptive grammars; they also apply to contexts where there is no agreement between the NP subject (in the 3rd plural person) and the verb (in the 3rd singular person) and yet to the lack of gender and / or number agreement morpheme on the predicative Adjectival Phrase, in copulative and transitive predicative constructions. This is the reason why, in the remaining of the paper, these terms will be in italic type.
} 
years), and three education levels (fundamental: 5 to 8 years; medium: 9 to 11 years; superior: more than 11 years).

A somehow comparable spoken corpus is used for Sao Tome and Principe (STP1), of 18 informants, distributed by gender, age and education level. However, in this case, only the first two age spans are covered (18-35 and 36$-55)$.

Finally, we also take into consideration the spoken subpart of the Africa Corpus (Bacelar do Nascimento et al, 2007), to collect some information regarding all African varieties and to provide some comparison with a previous study on agreement in predicative constructions based on the Africa Corpus (Miguel et al, 2012). This corpus covers the 5 African varieties (Angola, (ANG), Cape Verde (CV), Guinea-Bissau (GB), Mozambique, (MO) and Sao Tome and Principe (STP2).

Some caution is required due to the dimensions of the corpora considered in our study: each subcorpus of the Africa Corpus includes around 25,000 tokens, while the STP1 corpus has 80,117 tokens and the NIG corpus has 167,415 tokens. Table 1 gives the number of tokens of each of the spoken corpora under study.

Table 1: Number of tokens of the corpora of Portuguese Varieties

\begin{tabular}{|l|l|l|l|l|l|l|l|}
\hline & NIG & STP1 & ANG & CV & GB & MO & STP2 \\
\hline $\begin{array}{l}\text { Number } \\
\text { of tokens }\end{array}$ & 167,415 & 80,117 & 27,363 & 25,413 & 25,016 & 26,166 & 25,287 \\
\hline
\end{tabular}

\subsection{Outline of the paper}

Section 2 of the paper will be devoted to a general presentation of the most consensual findings of previous works on number partial agreement patterns inside NP or between NP in subject position, verb and predicative adjectives, mainly for Brazilian Portuguese, the most studied variety regarding these phenomena (aiming to remind that, in this variety, the existence of several dialects is recognized), but also for some spoken varieties of Africa. In section 3, we will try to account for partial number agreement in the full set of constructions inside the Noun Phrase we find in the corpora under observation, from simpler structures involving a unique determiner and a noun, to more complex structures with determiners, quantifiers and pre and post-nominal adjectives. The inclusion of the first contexts fulfils two goals: first, because they represent by far the most frequent NP structure in the oral corpora we are describing, they will help us state the most general pattern for partial agreement, in which speakers seem to operate a clear cut between the functional categories (determiners and existential quantifiers), with pure grammatical import, and the lexical categories, the noun heads; in second 
place they will reveal useful in order to see whether speakers applying partial agreement in these contexts extend this behaviour to all pre-nominal constituents. We will then turn to the constituents at the right of the noun head to observe the behaviour of post-nominal adjectives regarding agreement with the noun head.

In section 4 we will specifically address contexts that are defective regarding gender agreement. Finally, in section 5 we present a summary of our findings, comment on the data encountered and point some possible lines of analysis of the most significant patterns, in terms of parameters setting; and we present some final remarks in section 6 .

\section{Morphosyntactic agreement in Portuguese Varieties}

The comparison of the varieties of a pluricentric language as Portuguese may allow us to identify areas where variation phenomena show up. As far as morphosyntactic agreement is concerned, in several works about Brazilian Portuguese (BP), this variation has been described and accounted for (cf. Galves (1993), Scherre \& Naro (1998), Scherre (2001a), Scherre (2001b), Magalhães (2004), Costa \& Figueiredo (2006), Brandão \& Vieira (2007), Tenório (2008), a.o.). Furthermore, Gonçalves (1990), Gonçalves \& Stroud (1998), Inverno (2004), Figueiredo (2008), Jon-And (2010, 2011), Brandão \& Vieira (2012), Miguel et al. (2012), a.o., recognized the existence of (some) variable morphosyntactic agreement patterns, internally to the varieties spoken in Angola, just as in, Guinea-Bissau, Mozambique and Sao Tome and Principe.

The mainstream works on BP point to the co-existence of different grammars, internally to this variety - one with a partial agreement pattern, departing from the European variety, and another showing full agreement pattern, mirroring the European variety pattern:

"[...] variation regarding agreement in spoken Brazilian Portuguese is definitively internalized in the minds of its speakers. At this stage of the language, it is a matter of inherent variation, highly structured according to linguistic and social aspects." (Scherre, 1994:1, our translation)

However, in a panel study, Naro \& Scherre $(2003$, 2007) notice a substantial increase in the use of the full agreement pattern in Brazilian Portuguese, during the past years ${ }^{4}$, while Tavares Silva (2011) finds that,

${ }^{4}$ Notice that the referred works mainly inscribe themselves in Labovian variationism or in (generative) syntax frameworks. There seems to be few studies in the phonological field (but see Mota, this volume). Nevertheless, this last one seems to point to some compensatory phonological features /strategies allowing to 
from the seventies to the nineties, there is a gradual increase in the tendency to mark number only on "the first element of the NP", showing that this matter is still an open issue.

\subsection{Agreement inside NP}

The European variety of Portuguese (EP) categorically marks morphological plural by adding the suffix -s to the singular form of the noun and this agreement marker shows up in every single constituent of the Noun Phrase (determiners, quantifiers and adjectival modifiers):

PE: Todos estes livros novos coloridos. "all these books new colourful"

The gender category has to be treated independently from number due to its specific properties (cf. Ritter, E. (1991, 1993), a.o.). Gender marking on nouns, in Portuguese, shows the following properties:

(i) inanimate nouns have an intrinsic gender feature, fixed arbitrarily and codified in their lexical entry ( c cadeira $_{[\mathrm{fem}]}$ 'the chair', a pedra ${ }_{[\mathrm{fem}]}$ 'the stone', a casa $a_{[\mathrm{fem}]}$ 'the house', o banco ${ }_{[\mathrm{masc}]}$ 'the bank/bench'). The thematic class vowel $-a$ and $-o$ of the noun give some clue about the intrinsic gender of these nouns, although it is not always straightforward (cf. os problemas $_{[\mathrm{masc}]}$ 'the problems', a soprano $_{[\mathrm{fem}]}$ 'the soprano');

(ii) animate nouns can behave like inanimate ones, and be lexically codified for gender ( ${\text { m } \text { mulher }_{[\mathrm{fem}]} \text { 'the woman', o homem }}_{[\mathrm{masc}]}$ 'the man', a $\operatorname{cobra}_{[\mathrm{fem}]}$ 'the snake', o elefante ${ }_{[\mathrm{masc}]}$ 'the elephant'), or share the same form for masculine and feminine (o/a estudante 'the student', o/a dentista 'the dentist');

(iii) animate nouns can also show two different themes, the thematic class marker for accumulating the gender feature (alun(o/a $)_{[\operatorname{masc} / \mathrm{fem}]}$ 'student', $\operatorname{amig}(\mathrm{o} / \mathrm{a})_{[\mathrm{masc} / \mathrm{fem}]}$ 'friend').

Determiners (articles (o/a 'the'), demonstratives (estelesta) 'this'), indefinites (algum/alguma 'some'), possessives (teu/tua 'your') are marked for gender and agree with the gender feature of the noun head. Numerals are not marked for gender, with the exception of um/uma 'one' and dois/duas 'two'. Adjectives are marked regarding the gender category (lind $(o / a)$ 'beautiful'), except in the case of uniform adjectives (inteligente 'intelligent'). In EP agreement in gender shows up in every constituent of the Noun Phrase (except for uniform adjectives):

PE: Todás estâs lindas janela as abertâs.

"all these beautiful open windows"

preserve a phonological distinction between singular and plural forms (see, for example, Silva et al. (2007) for interesting insights on this issue). 
As for BP, a variety that, additionally to the categorical rule of full agreement inside the Noun Phrase, also exhibits patterns of variable number agreement, the works on this matter account for the existence of several defective agreement patterns. Not considering the agreement patterns in NPs embedded under prepositions or quite rare and inconsistent patterns, Scherre (2001b:93) notices that in BP, in all dialects, we may have a plural morpheme in all the NP constituents, akin the EP variety (1), but in non-standard dialects we may found the plural morpheme in the determiner and the noun head, but not in the post nominal adjectival modifier (2) or yet a single plural morpheme on the left most constituent; in this case, the definite or indefinite determiner (3a-b) :

(1) umas pessoas ricas

"some rich people"

(2) essas estradas nova $\varnothing^{5}$ "these new roads"

(3) a. $\quad$ as porta $\varnothing$ aberta $\varnothing$ "the open doors"

b. uns amigo $\varnothing$ "some friends"

It is worth noticing that, according to Simioni (2007), the pattern found in (4), below, without a plural morpheme on the left most constituent (the definite determiner, in this case), followed by plural marking on the noun head, and optional marking on the post nominal adjectival modifier represents an ungrammatical pattern, since it was not attested in BP adult speech.

(4) *A casas vermelha(s) [...] "the red houses" (cf. Simioni (2007), ex. (10))

\subsection{Subject-verb agreement}

The agreement patterns inside the NP illustrated in (1-3) are related to a more general feature of substandard varieties of BP (cf. Galves (1993), Naro \& Scherre (2003), Scherre et al. (2007), Costa \& Figueiredo (2006), Rodrigues (2006) and Mota (in this volume), among many others), involving subject-verb, as shown in (5-14). Two patterns seem to be at stake in this variety where, at least in informal speech, we may see a defective agreement pattern between subject and verb, and /or internally to the subject NP, when compared to EP. It is worth noticing that the third pattern quoted below is the core one, in the sense that it is the one uniformly used in written (formal)

${ }^{5}$ The symbol $[\varnothing]$ indicates that the plural morpheme does not have phonological content. 
register, recognized by prescriptive grammars, extending to all varieties of Portuguese.

Pattern 1: defective number agreement between the determiner and the noun head but full subject-verb agreement (5-6):

(5) os irmão $\varnothing$ dele nunca chegaram $[3 \mathrm{rd}$ plur] aos pés dele

"his brothers were never as good as he is"

(6) as garota $\varnothing$ praticamente não viveram ${ }_{[3 \text { rd plur] }}$ "the girls practically didn't live"

Pattern 2: defective number agreement between the determiner and the noun head in subject position and between the subject and the verb, where subject is a third plural person and the verb in a third singular person.

(7) as pessoa $\varnothing$ fica $[3$ rd sing] olhando "people keep staring"

(8) umas marquinha $\varnothing$ que servia ${ }_{[3 r d ~ s i n g]}$ para isso "some marks that were used for that"

(9) essas troca $\varnothing$ de experiência vai crescendo [3rd sing] "those exchanges of experience keep growing"

(10) aí veio ${ }_{[3 r d ~ s i n g]}$ aqueles cara $\varnothing$. "then came those guys"

Pattern 3: full number agreement inside the Noun Phrase in subject position and Subject-Verb agreement (all varieties)

(11) sobrinhos meus nunca levaram ${ }_{[3 \mathrm{rd} \text { plur] }}$ uma palmada "my nephews never received a slap"

(12) as mães hoje num ligam ${ }_{[3 r d \text { plur }]}$ pros filhos não "the mothers today don't pay attention to their kids"

(13) duas moças $[\ldots]$ estudaram ${ }_{[3 r d ~ p l u r]}$ "two girls studied"

(14) vieram $[3$ rd plur] os alunos "the students came"

So, roughly speaking, BP seems to be an example of a Portuguese variety where some dialects allow for a defective agreement pattern, both inside the Noun Phrase and between the Subject and the Verb, while EP categorically demands that full agreement apply, in both contexts. 


\subsection{Agreement in copulative and transitive predicative constructions}

In a previous study, based on the data collected from the available corpora of the five varieties of Portuguese spoken in Africa and on the Nova Iguaçu corpus, focusing on agreement in copulative, passive and complex transitive constructions (Miguel et al, 2012), we showed that for these varieties (i) agreement inside NP does not diverge in a significant way from the European variety: defective agreement inside NPs has quite a residual value; (ii) the cases where agreement between the NP in subject position and the copular verb did not apply were rare; (iii) the most dominant pattern in cases of lack of agreement in Nova Iguaçu consist of the absence of number agreement on the adjective or participle, although gender is marked (cf. (15)) ${ }^{6}$; (iv) in the African varieties, the most frequent pattern consists of lack of number and gender agreement on the adjective or participle: in these cases, the less marked form, the singular masculine, is found, regardless of the [+/- plural] features exhibited by the NP in subject position or the [+/- masculine] feature of the noun head (cf. (16)).

(15) as vagas são muito limitada (NIG)

"vacancies are very limited"

(16) muitas pessoas ainda tem que ser informado (GB)

"many people have yet to be informed"

One possible analysis of these data is to propose that, for these speakers, the verb and the adjectival predicate are analyzed as a complex predicate of the form [Verb-Adjective]: the verb carries mood, tense and aspect information and is marked for person and number in agreement with the subject. In BP and in the African varieties, since number is found on the verb, it is redundant to mark it on the adjective; by the contrary, no gender mark is found on the verb and, consequently, the adjective carries gender agreement. Verb and adjective carry compositely number and gender marks:

$$
\text { 7) }\left[\left[\mathrm{NP} \text { subject }{ }_{\text {gender }+ \text { number }}\right]\left[\left[\text { Predicate }\left[\mathrm{V}_{\text {person+number }}\right] \text { [adjective }{ }_{\text {gender }}\right]\right]\right.
$$

In the cases where no gender agreement is marked on the adjective, in the African varieties, speakers may be treating gender in the adjective as a lexical feature and selecting the less marked form. Notice that, although we will not go into many details concerning gender agreement in the present work, the data for the varieties in Africa seem to confirm a certain propensity to neutralize gender agreement, as well as number agreement in post-nominal adjectival modifiers inside NPs.

\footnotetext{
${ }^{6}$ See, for BP, Scherre (1991).
} 
So, in what concerns agreement inside the noun phrase, the lack of significant quantitative data in this previous study does not enable us to infer the emergence of (some kind of) competing grammars in these varieties.

As EP categorically marks number and gender categories on all constituents inside the NP, in the next section we will focus on the Brazilian and on the African varieties of Portuguese ${ }^{7}$.

\section{Number agreement in noun phrases in Portuguese Varieties}

We turn now to the analysis of number agreement inside noun phrases in the corpora described in section 1.2. We first present the results concerning Nova Iguaçu (section 3.1) and then those from the African varieties, especially from the corpus STP1. In both cases, we start by looking at the left periphery of the noun phrase and move then to the right periphery.

\subsection{Number agreement in the corpus of Nova Iguaçu (BP)}

\subsubsection{The left periphery ${ }^{8}$}

The lack of number agreement inside NPs is frequent in the corpus of Nova Iguaçu. In fact, two of the informants specifically mentioned agreement in number when talking about differences in the way people speak Portuguese and even consider it as a deviation from what one of them considers to be "correct", as we reproduce in (18) and (19):

(18) o meu irmão passou a ser, um cara que você, estranhava ele, ele se vestia como um feirante, você chamava ele pra uma festa, ele botava camisa quadriculada e calça vermelha, ele passou a não combinar mais nada, o falar dele mudou, não era mais "dez reais" era "dez real" (NIG-B-1-H)

"my brother became, a guy that you, wouldn't recognise, he dressed like a marketer, you would invite him to a party, he would dress a quadricular shirt and red pants, he wouldn't match anything anymore, the way he talked changed, it wasn't 'ten reais ${ }_{[\mathrm{pl}]}$ ' [Brazilian currency] it was "ten real $[\mathrm{sg}]$,"

(19) nossa você tá falando muito errado cara, (...) igual meu sobrinho, fala dez real ai eu acho isso horrível, cara eu to conversando com você ai tia quanto foi isso? ah isso aqui custou vinte reais, nossa mas vinte real é muito caro será que ele não viu que eu falei certo não (NIG-B-1-M)

${ }^{7}$ We refer to Brandão, in this volume, for the analysis of data of the European variety. Indeed, her study shows that cases of lack of agreement are extremely scarce in all subcorpora of EP.

${ }^{8}$ In what follows, the term 'left / right periphery' refers to the constituents, inside NP, to the left or to the right of the Noun Head. 
“oh my, you are not speaking correctly, (...) just like my nephew, he says ten real ${ }_{[\mathrm{sg}]}$ and I think this is horrible, we are talking 'aunt, how much was this' 'this costed me twenty reais ${ }_{[\mathrm{pl}]}$ ', 'but twenty real ${ }_{[\mathrm{sg}]}$ is really expensive' didn't he notice that I spoke correctly”

In noun phrases with a specifier and a noun head, the most frequent pattern is for the agreement in number to be marked only on the specifier, and not on the noun (cf. (20)), as previously observed by the works above referred, among others. We consider as constituents in the specifier position determinants and quantifiers (definite and indefinite articles, demonstratives, indefinites, possessives, numerals).

(20) a. eu entrei no banco para depositar um dinheiro, os cara entraram, assaltaram o banco e me pegaram como refém (NIG-B-1-H)

"I came into the bank to deposit some money, the men came in, robbed the bank and took me as hostage",

b. ah, porque tem muitas mãe que não, não educam os filho direito né (NIG-A-1-M)

"because there are many mothers that don't raise their kids right"

This pattern stands out due to the number of its occurrences (205 cases) when compared with the other patterns of lack of agreement marks in the Nova Iguaçu corpus (these patterns attain no more than 20 occurrences).

The opposite option, to mark the agreement in number on the noun head (cf. (21)) occurs in 12 contexts ( 7 are quantifiers).

(21) tem um/ dois primo meu que o pais deles se separaram agora há pouco tempo (NIG-A-1-H)

"there is one / two cousins of mine, their parents separated not long ago"

As far as this pattern is concerned, we saw, in section 2, that Simioni (2007) disregards it, because it is not attested in the speech of adults. We do encounter these cases in the Nova Iguaçu corpus. However, their number of occurrences is low when compared to the dominant pattern, and it may be the case that these are mere production errors. This is a question that falls beyond the scope of this paper and that would require further data.

We found 205 occurrences of NPs with number marks on the determiners and quantifiers and no plural morpheme on the head noun. Looking with more detail at the different categories filling the left periphery of these NPs,

${ }^{9}$ In the examples from our corpus, we mark in bold the number and gender morphemes and we underline the constituents that lack marks of number and/or agreement. Since constituents defective in agreement are signalled in the examples, we provide English translations of the Portuguese sentences, without any concern with lack of agreement marking. 
we find definite articles (43 occurrences), indefinite articles (8), demonstratives (43), indefinites (24), possessives (14), and numerals (50).

There are only two cases of noun phrases with a pre-nominal adjective and a noun head, and both have number agreement marked on the adjective as we illustrate in (22):

(22) a. aqui dentro do nosso bairro não tem grandes coisa também é o que eu explique pra você (há um) tempo atrás nós temos a praça (NIG-B-2-M)

"here in our neighbourhood there aren't many things, that's what I explained to you some time ago, we have the square"

b. eu convivo sempre convivi né com pessoas de diversas assim cultura né (NIG-C-2-M)

"I interact, I've always interacted with people from different cultures"

Notice that these contexts, where the plural morpheme appears on the first constituent of the Noun Phrase, are akin to those involving a determiner or quantifier and a noun (cf. (7-10), and (20), above). These data are summarized in Table 2 (the examples represent a type of NP structure).

Table 2: Patterns of defective number agreement, in NPs with a single element in the left periphery

\begin{tabular}{|l|c|}
\hline Context & $\mathbf{N}^{\mathbf{0}}$ of occurrences \\
\hline os filho $\varnothing$ & 205 \\
\hline grandes coisa $\varnothing$ & 2 \\
\hline o $\varnothing$ pais & 12 \\
\hline
\end{tabular}

When there are two or more constituents in the left periphery, the most frequent pattern (17 cases) is the one where both determiners show marks of agreement in number, as illustrated in (23):

(23) a. eu eu com as minhas filha apesar de eu, do meu jeito meio meio coisa de ser mas eu procuro ter muito diálogo com elas, procuro até brincar (NIG-C-1-H)

"me with my daughters, in spite of the way I am, I try to talk a lot with them... I even try to play"

b. também foi só isso por aqui, só esses dois caso mesmo de assalto (NIG-C-2-H)

"that was the only thing around here... only those two cases of robbery" 
The number of occurrences shows that agreement in number is preferably not marked only on the first element on the left, but rather on the constituents fulfilling the same function: determiners and quantifiers. We will come back to this issue in section 5 .

There are three cases of number being marked on the second pre-nominal element as well as on the noun head, as in (24), but this is not a significant pattern when compared to the number of occurrences of cases of the type of (23) and in one of these occurrences (cf. (24b)) the speaker corrects himself and produces an NP with total agreement.

(24) a. eu acho que a parte difícil que você passa na vida é quando você tá criando o teus filhos (NIG-B-1-M)

"I think that the difficult part in life is when you are raising your children"

b. então o nossos políticos, primeiro lugar, eu acho que os nossos políticos eles são muito mal preparados (NIG-B-1-H)

"so our politicians, first, I think that our politicians they are really not well prepared"

Table 3 summarizes the patterns encountered in the left periphery of the NP. The most significant patterns show marks of agreement on the determiners or adjectives occupying the left periphery and lack of number marks on the noun head (first three rows).

Table 3: Patterns of defective number agreement in the left periphery

\begin{tabular}{|l|c|}
\hline Context in the left periphery & $\mathbf{N}^{\mathbf{0}}$ of occurrences \\
\hline 1. os filho $\varnothing$ & 205 \\
\hline 2. grandes coisa $\varnothing$ & 2 \\
\hline 3. as minhas filha $\varnothing$ & 17 \\
\hline 4. o $\varnothing$ pais & 12 \\
\hline 5. $\varnothing \varnothing$ nossos políticos & \\
\hline
\end{tabular}

Other agreement patterns occur a single time in the corpus and are consequently non significant. In these cases, the number agreement is found on the first specifier (25a); on the second specifier (25b), on the first specifier and on the noun $(25 \mathrm{c})$. 
(25) a. em vez de eu fazer Maria Chiquinha nas minha netinha eu vou ter que fazer trancinha ((risos)) é um preconceito (NIG-B-1-M)

"instead of making a pigtail to my granddaughters I will make them tresses (laugh), it's a prejudice"

b. olha eu não sei sabe eu eu, eu vejo eu, eu tiro assim, por a minhas filha (NIG-C-1-M)

"look I don't know, I see from my daughters"

c. eles, fizeram tudo que tinham que fazer para manter a ordem no Império, que desagradou, os tal políticos da época, principalmente os liberais (NIG-A-3-H)

"they did everything to keep the Empire in order, and it displeased those politicians at the time, mostly the liberals"

In one case with specifier and pre-nominal adjective, only the possessive does not show a plural mark (cf. (26)).

(26) quais são as suas dificuldades? as sua maiores dificuldades? nessa profissão? (NIG-A-1-M)

"what are your difficulties? ... your more important difficulties? In this profession?

As we observed before regarding the case where agreement in number only appeared on the noun head (cf. (21)), these occurrences have low significance and don't constitute any consistent pattern, but are helpful in the sense that they show some variation in the way speakers mark agreement in number.

There are two important comments that help to put in perspective the data from Nova Iguaçu. The first aspect that we need to consider is the fact that some bare nouns (11 occurrences) do not receive the plural marks in contexts where a plural entity is referred, and the bare singular noun seems to be interpreted as expressing kind (i.e, special types of individuals well established in the background knowledge of speaker and hearer (Krifka et al., $\left.1995)^{10}\right)$. We found contexts with the nouns coisa 'thing' (3 occurrences), filho 'son', estudante 'student' and parte 'part', as illustrated in (27). In these contexts, the plural nature of these nouns seems to be lexically encoded, instead of morphologically marked with a final plural ending [-s].

10 We do not take into consideration here possible differences in the meaning of sentences with kind-referring NPs in our sample. It would be important, for example, to evaluate whether we face mostly a kind predicate interpretation (predication over a kind) or a collective property interpretation, where the property "holds of the actual instances (as a group), and not of the abstract object, the kind" (Krifka et al, 1995:79-80, among others). This question would need to be addressed in a follow-up of this study. 
(27) a. mas ela tava deixando assim minha filha muito livre ela começou a fazer coisa assim (NIG-C-1-M)

"but she was giving a lot of freedom to her daughter, she started to do things"

b. D: você acha que hoje em dia é mais fácil ou mais difícil educar os filhos? L: é: educar filho em que sentido? (NIG-C-1-H)

"D: you think that today it's easier or more difficult to raise children? L: to raise children in what sense?"

The second aspect is the fact that even the fixed expression em termos de 'in terms of' lose the plural mark on the noun, as in (28), where we find instead em termo de:

(28) eu acho que, tá difícil de realmente se criar uma identidade no Brasil, eu acho que em termo de cultura, o Brasil não tem nenhuma, nós temos a dos índios mas que nem comemoramos (NIG-A-3-H)

"I think that, it's difficult to create a Brazilian identity, I think in terms of culture, Brazil has none, we have the one of the Indians, but we don't celebrate it"

In fact, we even find contexts of proper nouns with loss of the fricative in coda position. One of the informants in Nova Iguaçu produces 6 times the proper noun "Roberto Carlo", instead of "Roberto Carlos", and one time the proper noun with the final fricative, as in (29).

(29) eu sempre, mas eu sempre, Roberto Carlo mas, sempre gostava de ouvir todos eles até hoje eu tenho ali Roberto Carlo tenho o cd, cento e setenta e seis músicas do Roberto Carlos que eu mandei fazer (NIG-C-2-H)

"I always, but I always, Roberto Carlo but, I always liked to listen to all of them, today still I have there Roberto Carlo I have the cd, one hundred seventy six songs from Roberto Carlos that I've compiled"

In these particular contexts, the lack of number marks on the noun head, as well as the lack of fricative in coda position in the proper name seem to go beyond purely morphological agreement phenomena.

Summing up this section, we found that the determiners, quantifiers and adjectives filling in the left periphery exhibit number agreement morpheme, while the noun head lacks plural marks. This is true even in more complex structures in the left periphery, with several determiners/quantifiers and adjectives. We found a significant high number of occurrences of noun heads which are semantically plural although defective in plural marks, and which seem to be kind-referring expressions. 


\subsubsection{The right periphery}

Let's now observe the right periphery of the noun phrase. In contexts with a bare noun followed by an adjective, the most frequent pattern is for the noun to show plural marks but not the post-nominal adjective (20 occurrences), as in (30):

(30) eles têm filhos pequeno (NIG-B-1-H) "they have small children"

The opposite pattern, illustrated in (31), with marks on the adjective and not on the noun is found only in 5 cases.

(31) tem ônibus pra tudo quanto é lugar tem metrô Pavuna trem, essas coisas, ponto positivos né? (NIG-A-2-M)

"there are buses going everywhere, there is the subway "Pavuna train", all these things, positive aspects, right?

The fixed expression em termos $+\mathrm{ADJ}$ 'in ADJ terms' is also realized with no plural marks in the noun (nor the adjective), just like we observed for the expression em termos de, above:

(32) eu acho que, em termo profissional, só se eu fosse para o lado da informática mesmo, que eu gosto muito (NIG-A-3-H)

"I think that, in professional terms, only if I turned to informatics, which I like a lot"

The universal quantifier todo occurs 18 times in the right periphery of the noun. In 12 cases, we find the expression essas coisa toda, with plural marks only on the left periphery of the noun. This expression seems to have some degree of fixedness and a specific meaning of referring to an open list of situations, or even a pragmatic function of closing the utterance, as illustrated in (33).

(33) aí eu/ aí eu fui trabalhar à noite no Estadão jornal, entendeu essas coisa toda, sempre trabalhei/aí (NIG-C-2-H)

"then I started working at night at the Estadão newspaper, you see, all these things"

There are other 3 cases with the same agreement pattern and another noun head, as in (34), while in 5 occurrences both specifier and noun receive plural marks (cf. (35)). Notice that this last pattern occurs a single time with the noun coisa, which reinforces the possibility of interpreting "essas coisa toda" as a semi-fixed expression. 
(34) aí acabou, que aí venderam os instrumento todo, foi pra frente não (NIG-C-2-H)

"at that point it ended, because they sold all the instruments, it didn't go on"

(35) a gente reúne os filhos todo aí a gente faz um almoço legal (NIG-C$-1-\mathrm{M})$

"we bring together all the children, we make a nice lunch"

These two patterns are also found with post-nominal adjectives. The plural mark is assigned to the sole specifier (cf. (36)) in 13 cases (in 4 of them the adjective is modified by an adverb); or the plural is marked on both specifier and noun (cf. (37)) in 17 cases, 3 of them with a modified adjective.

(36) eu por exemplo eu falo umas palavra errada também (NIG-A-2-M) "me, for exemple, I also say some incorrect words"

(37) foi o pior governador que nós tivemos, ele, principalmente com esses transportes alternativo (NIG-A-3-H)

"he was the worst governor that we had, he, especially with alternative transportation"

Differences in number of occurrences between these two patterns are not significant: what stands out is the fact that agreement in number is not marked on the post-nominal constituents, but rather on the constituents of the left periphery. We summarize the set of patterns in the right periphery for Nova Iguaçu in Table 4.

Table 4: Patterns of defective number agreement patterns in NP in Nova Iguaçu

\begin{tabular}{|l|c|}
\hline Contexts in the right periphery & $\mathbf{N}^{\mathbf{0}}$ of occurrences \\
\hline \hline filhos pequeno $\varnothing$ & $\mathbf{2 0}$ \\
\hline ponto $\varnothing$ positivos & 5 \\
\hline \hline esses negócio $\varnothing$ todo $\varnothing$ & 3 \\
essas coisa $\varnothing$ toda $\varnothing$ & 12 \\
\hline as regras toda $\varnothing$ & 5 \\
\hline \hline umas palavra $\varnothing$ errada $\varnothing$ & $\mathbf{1 3}$ \\
\hline esses transportes alternativo $\varnothing$ & $\mathbf{1 7}$ \\
\hline
\end{tabular}


Summarizing the above observations, it seems that several factors are important to account for number agreement in Nova Iguaçu: the position inside the NP, with a clear difference between left and right periphery; the function, since agreement marks tend to appear on all the determiners and quantifiers, and not only on the first element in the left periphery; the possible tendency to interpret some nouns as kind-referring terms, thus appearing in singular form; some tendency to lose fricatives in coda position.

\subsection{Number agreement in the corpora of the African varieties}

We will discuss the 5 African varieties simultaneously, while comparing them with the data presented in the previous section for Nova Iguaçu. This will enable a contrastive analysis of the agreement patterns in the 6 varieties. We are considering the 5 comparable corpora of the African varieties included in the Africa Corpus, as well as the more extensive corpus of S. Tome and Principe - STP1. Since the corpus STP1 is closer in terms of internal constitution and number of tokens to the corpus of Nova Iguaçu, we will center our discussion on these two sets of data and complement them with the Africa Corpus, so as to cover the other African varieties.

\subsubsection{The left periphery}

The tendency observed in Nova Iguaçu to use nouns with no plural marks when referring to a plural set of entities is encountered in the corpus STP1 (14 cases), and also in the corpus STP2 (5 cases), as in example (38).

(38) se eu não tenho um amigo cheio de recurso, ninguém me estende uma mão (STP1_21)

"if I don't have a friend with means, no one gives me a hand"

In what concerns noun phrases with a specifier and a noun, data from the STP1 corpus points to the same emerging patterns as Nova Iguaçu, and so do the other corpora of the African varieties (of course, one has to take into consideration that the Africa Corpus spoken subpart is much smaller than the STP1 and even more than the Nova Iguaçu corpus).

So, in the Santomean variety (looking now at STP1), although the number of NPs with partial agreement between the determiner and the noun head does not, globally, reach the rates we meet in NIG (205 vs. 135), it is still a very significant pattern.

If we consider the constituents to the left of the noun head, the most frequent pattern is the determiner [+plural] and Noun [-plural]: we found 22 cases with a demonstrative, 20 cases involving a definite article, 5 cases with the indefinite article, and, finally, 7 cases with a possessive in pre-nominal absolute position - let us remind that in the EP variety, the possessive in pre- 
-nominal position is generally preceded by a definite article ${ }^{11}$. We illustrate below some of these contexts:

(39) às vezes as pessoas utilizam essas música mas em verso. (STP1_21) "sometimes people use these musics but in verse"

(40) (...) só os criado do comandante pode (...) (STP1_69) "only the maids of the commander may (...)"

(41) (...) não chegou para ir para internar deu assim para tomar uns medicamento mesmo em casa (...) (STP1_32)

"it wasn't necessary to stay at the hospital, it was possible to take some medicines at home"

(42) Eu prefiro estar sozinha como eu estou, sacrificar, por mim mesma, por meus filhos, minhas responsabilidade. (STP1 90)

"I prefer to be alone as I am, to sacrifice for myself, for my children, my responsabilities"

As for the NPs introduced by an indefinite quantifier, we collected 18 cases, illustrated in (43):

(43) (...) e S. Tomé não tem muitas experiência nessas base não, (...) (STP1_32)

"S. Tome doesn't have a lot of experience on those matters, no"

It is worth noticing that, within Quantified Noun Phrases exhibiting partial agreement, there was a great rate of cases involving numerals (64 occurrences) and these last cases represent almost $50 \%$ of the total number of the partial agreement pattern in itself (135); they also represent the great majority of cases involving indefinite quantifiers; in turn, the total cases involving indefinite quantifiers and numerals represent the most frequent pattern of partial agreement found. Although this might be a mere coincidence, due to the corpus nature, it matches the results of Nova Iguaçu (cf. (44)). In the last section of the paper we will try to address this question.

(44) (...) eu tenho dois filho e eu tenho que ter três balde de água (...) (STP1_40)

"I have two children and I need to have three buckets of water"

The same pattern as in (39)-(40), above, is also found in Angola and Mozambique where the number of occurrences stand out (cf. (45)-(46)). In Mozambique, 17 cases are encountered ( 8 are numerals), while in Angola we found 23 cases (4 numerals and 3 indefinites). The Mozambican variety

11 See Müller (1997), Castro (2001), Brito (2001), Miguel ((2002), (2004)), Rinke (2010). 
shows the same tendency for numerals in the pattern where the noun head lacks number morpheme, but this needs to be confirmed with more data. In Guinea-Bissau and Cape Verde, the number of occurrences is extremely low.

(45) é um hábito que está a ser adoptado por outras etnia. (ANG_04) "It's a custom that is being adopted by other ethnical groups"

(46) tentar minimizar ultimamente a situação dos transporte (MOC_09) "try lately to minimize the situation of transportation"

The opposite pattern, with number marking on the noun head and not on the specifier is residual in STP1, Angola and Mozambique, just as in the data from Nova Iguaçu. We give an example of such cases for the Mozambican variety:

(47) nem chega para comprar o o alimentos (MOC_09) "it's not even enough to buy food"

Occurrences with pre-nominal adjectives are extremely rare, but these few cases follow the same pattern as specifiers. A summary of the data is presented in Table 5 .

Table 5: Patterns of defective number agreement patterns in the left periphery with simple NP, in all varieties

\begin{tabular}{|l|r|r|r|r|r|r|r|}
\hline & \multicolumn{1}{|l|}{ NIG } & STP1 & STP2 & ANG & CV & GUI & MOC \\
\hline os filho $\varnothing$ & $\mathbf{2 0 5}$ & $\mathbf{1 3 5}$ & & $\mathbf{2 3}$ & $\mathbf{2}$ & $\mathbf{3}$ & $\mathbf{1 7}$ \\
\hline grandes coisa $\varnothing$ & 2 & 2 & & 1 & & 3 & \\
\hline o $\varnothing$ pais & 12 & 4 & & 2 & 2 & & 2 \\
\hline
\end{tabular}

The above contexts only involve simpler NPs of the form [Det / Q + Noun Head], but in the STP1 corpus, we find NPs of a more complex structure on the left periphery, involving two constituents to the left of the Noun Head.

In most of the cases (13 occurrences), we find the plural morpheme on both the constituents to the left of the Noun Head, regardless of the subclass of the first constituent - definite article (48-50), demonstrative (51) indefinite article (52), or universal quantifier (53):

(48) Cada um tem as suas possibilidade (STP1_31)

"each one has its possibilities" 
(49) não tem estado a fazer coisas que como as outras igreja, né (...) (STP1_40)

"they are not making things like the other churches, right"

(50) eu não falo das outras raça (STP1_22)

"I don't talk about the other races"

(51) Porque nesses últimos tempo, por vezes, dezanove horas, vinte horas ouve-se que pessoa está a roubar. (STP1_40)

"because in these recent times, sometimes, nineteen hours, twenty hours, we hear that someone is stealing"

(52) se for para assentar uns cem bloco (STP1_110)

"if the objective is to lay about a hundred blocks"

(53) A tentar acumular lixo todos os dia dentro de quintal porque não tem onde deitar lixo (STP1_31)

"trying to accumulate garbage every day in the backyard because there is no place to throw the garbage"

Regarding the combinatory possibilities that were found, notice that the second constituent, in linear position, to the left of the Noun Head may be a possessive (48), some sort of quantitative adjectives, akin 'adjectival quantifiers' (50-51), a numeral (52) or yet the definite article under the scope of a universal quantifier (53).

In some cases ( 5 occurrences), we found contexts where only the left most constituent was a morphological plural (see (54-55), but being so few, they are not an easy issue.

(54) Chega fim de mês, tem os seu salário (STP1_90)

"when the end of the month comes, they have their salary"

(55) há umas certa regra que eu não, não dá para cumprir (STP1_40) "there are certain rules that I don't, that it is not possible to follow"

The other African varieties also point to the same pattern in cases of more complex structures in the left periphery: number is marked over the two constituents in specifier position. There is only one occurrence, in the Angola corpus, of a context where the second specifier and the noun are both receiving plural marks (cf. (56)). The number of occurrences in the left periphery found in the Africa Corpus is consistently low, with the exception of Angola. Table 6 summarizes these data.

(56) o próprios ensinamentos (ANG_04)

"the teachings themselves" 
Table 6: Patterns of defective number agreement in the left periphery with more complex NP structures, in all varieties

\begin{tabular}{|l|l|l|l|l|l|l|l|}
\hline & NIG & STP1 & STP2 & ANG & CV & GUI & MOC \\
\hline as minhas filha $\varnothing$ & $\mathbf{1 7}$ & $\mathbf{1 3}$ & $\mathbf{1}$ & $\mathbf{7}$ & $\mathbf{1}$ & & $\mathbf{1}$ \\
\hline o $\varnothing$ nossos políticos & 3 & & & 1 & & & \\
\hline
\end{tabular}

\subsubsection{The right periphery}

Since one of our goals was to pay special attention to the sequences involving pre- and post-nominal adjectives, beside the observations in the previous paragraph, regarding quantitative pre-nominal adjectives / adjectival quantifiers, a note on post-nominal adjectives is in order.

We must point out that the structures where a determiner is followed by a Noun Head and a post-nominal adjective were quite rare (13 occurrences), nevertheless, there seems to be two patterns almost equally represented: one where both the determiner and the Noun Head exhibit plural morpheme (cf (57-60)) and one another, where only the determiner shows number marking (61-63). However, in both cases, the post-nominal adjective is defective for number, appearing in the singular form but exhibiting gender agreement with the Noun $\mathrm{Head}^{12}$, an agreement feature that was also noticed for adjectives in predicative position in previous work in these corpora of the 5 African varieties (Miguel et al (2012)). The post-nominal adjective being modified by an adverb does not seem to interfere in this pattern (see (59), or (60) and (63)) - the two last cases involving a uniform adjective.

(57) Os tempos livre em casa não é ? (STP1_22) "free time at home, right?

(58) (...) as condições financeira não permitia prosseguir (STP1_110) "the finantial conditions didn't allow to proceed"

(59) havia as pessoas mais velha (STP1_110) "there were older people"

(60) normalmente nessas zonas assim mais distante as pessoas são ligeiramente mais humildes (STP1_47)

"usually in more distant areas, people are slightly humbler"

(61) já vi cobra, eh, já vi vários bicho perigoso (STP_110) "I've seen snakes, I've seen several dangerous animals"

12 If they are not uniform adjectives. 
(62) cacharamba mete açúcar e é feita com essas cana aguada que não é muito doce (...) (STP1_40)

"cacharamba takes sugar and it is made with these watery sugar canes that are not too sweet"

(63) morre aquelas lula mesmo grande (STP1_110)

"these really big squids die"

Absence of plural marks on the adjective is also found in the Africa corpus (see number of occurrences in Table below). When there is no specifier, the plural mark is found on the noun, when there is a specifier, data show that the plural tends to be marked on both specifier and noun, as in the STP1 data in (60)-(63), above. The African varieties point to the same preferred pattern as the ones observed in the corpus of Nova Iguaçu and STP1, but the number of occurrences is considerably lower. See Table 7 for a summary of the data.

Table 7: Patterns of defective number agreement in the right periphery, in all varieties

\begin{tabular}{|l|l|l|l|l|l|l|l|}
\hline & NIG & STP1 & STP2 & ANG & CV & GUI & MOC \\
\hline filhos pequeno $\varnothing$ & $\mathbf{2 0}$ & $\mathbf{1 1}$ & & $\mathbf{1}$ & $\mathbf{2}$ & $\mathbf{3}$ & \\
\hline ponto $\varnothing$ positivos & 5 & & & & & & \\
\hline umas palavra $\varnothing$ errada $\varnothing$ & 13 & 4 & 1 & 1 & & 1 & \\
\hline esses transportes alternativo $\varnothing$ & $\mathbf{1 7}$ & $\mathbf{1 8}$ & $\mathbf{2}$ & $\mathbf{2}$ & $\mathbf{2}$ & $\mathbf{2}$ & $\mathbf{4}$ \\
\hline
\end{tabular}

Notice that, for Africa, in the whole sample, there are only two occurrences (in Angola and STP1) with a post-nominal universal quantifier ${ }^{13}$, and the first

13 The universal quantifier occurs in the left periphery of the noun, preceding the definite article, both in STP (cf. (53)), and in Nova Iguaçu (cf. (i)).

(i) mas eles não não, todos os político não é nem o Lindinho, em si todos em geral todos prometem e não fazem nada (NIG-A-2-M) 'but they don't don't, all politicians (...) they all promise and do nothing'

In fact, it is assumed that the universal quantifier takes a plural definite NP as complement (Müller et al. 2007); so, we would have to say that, in fact, the universal quantifier and its definite NP complement are not exactly inside the same constituent; the case involving this category should be treated apart and todo would deserve a complete study in all the varieties.

But todo may also appear in post-nominal position, in all varieties. Notice that in speakers displaying partial agreement, todo, in this position, may appear without plural marks, behaving exactly as other post-nominal adjectives (for Nova Iguaçu, cf. (33-(35) and also (ii), below; for STP1, cf. (64)).

(ii) as pessoas tem que vim pro centro pra poder manipular banco esses negócio todo NIG-B-3-H 'people have to come to the center to be able to manipulate the banks all these businesses' 
one (Angola) follows one of the patterns found in the Nova Iguaçu corpus (the determiner and the noun head are marked for plural), while the other (STP1) follows the other pattern, with plural marking only in the determiner:

(64) a. após essas transfomações toda (ANG_04)

"after all these transformations"

b. esses tempo todo, então ele fazia uma visita lá em casa (STP1 110)

"all this time, then he would pay a visit at home"

\section{Gender agreement in Noun Phrases}

\subsection{Gender agreement in Nova Iguaçu}

Contrary to agreement in number, the lack of agreement in gender is rare in the corpus of Nova Iguaçu. There are 8 occurrences of lack of gender marks on the specifier (cf. (65)). However, in 2 cases, the speaker immediately corrects its utterance, as exemplified in (66):

(65) isso vira um bolo de neve e quando chegar lá no final você não tem mais uma família, você tem uma conjunto, digamos assim, de filhos (NIG-A-3-H)

"it turns into a snow ball and when it ends you don't have a family anymore, you have a set of, let's say, children"

(66) isso não pode acontecer, eu acho que nosso constituição, nossa constituição já, acabada, não temos mais (NIG-A-3-H)

"it can't happen, I think that our constitution, our constitution, finished, we don't have it anymore"

There are other 3 cases where the post-nominal adjective does not show gender marks:

(67) a. eu acho que, para se criar uma identidade no o Brasil hoje, ou que seje pelo esporte, mas não vai ser uma coisa, assim, amplo, nacional (NIG-A-3-H)

"I think that to create an identity in Brazil today, maybe through sports, but it won't be something broad, national"

This agreement pattern may be an interesting question for the 'quantifier floating' issue, which poses that in examples such as (iiib-c), the universal quantifier is stranded behind the NP he selects, while in (iiia), it occupies its basic position.

(iii) a. All the boys seemed to be in a good mood when they arrived. b. $\quad$ The boys all seemed to be in a good mood when they arrived. c. The boys seemed all to be in a good mood when they arrived.

(examples (iii) were taken from: http://grammar.about.com/od/pq/g/ Quantifier-Floating.htm) 
b. aquele mártir que lutou por alguma coisa, por exemplo, se tivesse uma guerra civil, eh, americano, eh, uma guerra civil brasileiro, talvez isso pudesse dar $\mathrm{u}$, uma, uma identidade para o Brasil (NIG$-\mathrm{A}-3-\mathrm{H})$

"that martyr that fought for something, for example, if there was a civil war, American, a Brazilian civil war, maybe that could bring an identity to Brazil"

Indeed, there are few contexts with lack of gender agreement inside the NP and this proves not to be a significant phenomenon in the corpus of Nova Iguaçu.

\subsection{Gender agreement in the African varieties}

The Africa Corpus and the STP1 Corpus point to a more significant number of contexts with lack of agreement in gender, compared to what we found in Nova Iguaçu. This follows the conclusions of previous studies on predicative constructions already sketched in section 2 (Miguel et al, 2012).

We summarize in Table 8, below, the number of contexts where one of the constituents inside the nominal phrase lacks gender marks. Considering the dimension of the Nova Iguaçu corpus, the number of contexts with lack of gender agreement is significantly low. However, in the Nova Iguaçu corpus, there is more mismatch gender between the determiner and the noun head, also attested in all the other varieties, especially in Mozambican Portuguese. Although we do not find all the patterns in the 5 African varieties of Portuguese, they do contrast with the results found for Nova Iguaçu. The data from the corpus of Guinea is especially interesting since more occurrences of lack of gender marks were registered, in total.

In general, the data point to the following patterns: when there is mismatch of gender agreement, it tends to affect the specifier (68), or the specifier and the pre-nominal adjective (69); or the post-nominal adjective (70). In the latter case, in the Corpus of Guinea, the specifier may have gender marks (70a) or not (70b), although the first case is the more frequent pattern when taking into consideration all the varieties. An overview of the number of occurrences is given in Table 8.

(68) a. ver aqueles crianças, que são pessoas da rua (MOC_04)

"to see these children, that are people from the street"

b. agora, para uma homem que se apaixona, enfim, normalmente que não tem nada a ver com conceitos ou clichés (ANG_04)

"but for a man that falls in love, well, usually it has nothing to do with prejudice or cliche"

(69) então, o jovem vejo um único solução: é entrar por exemplo na via de droga (GUI)

"then, for young people, I see only one solution: to take the path of drugs" 
(70) a. abracei essa profissão, ah, de uma forma inesperado (GUI) "I embraced this profession in an unexpected way"

b. que durante o fim do mês tem um garantia mínimo, um subsídio (GUI)

"that at the end of the month has a minimum guarantee, a subsidy"

Table 8: Patterns of defective gender agreement in all varieties

\begin{tabular}{|l|r|r|r|r|r|r|r|}
\hline & NIG & STP1 & STP2 & ANG & CV & GUI & MOC \\
\hline nosso constituição & 8 & 3 & & 4 & 1 & 2 & 10 \\
\hline um único solução & & 2 & & 1 & 1 & 4 & \\
\hline cor esverdeado & & 4 & 2 & & & 8 & \\
\hline uma forma inesperado & 2 & 4 & 1 & & 3 & 2 & \\
\hline um garantia mínimo & & & & & & 2 & 1 \\
\hline
\end{tabular}

\section{Overview and first steps into understanding the data}

\subsection{Summary of the patterns encountered}

Summarizing the corpora results for the varieties under observation,

1. In NPs with simpler structure $(\operatorname{det} / \mathrm{Q}+\mathrm{N})$, we noticed a substantial number of occurrences involving defective agreement, between the determiner (definite article, indefinite article and demonstrative or yet possessives in absolute initial position) exhibiting a plural morpheme and the Noun Head, the last one appearing unmarked for morphological plural; this is the most accounted pattern for BP; in oral productions these seem also to be the most frequent kind of structures found in NPs. In this sense, they seem to build a strong piece of evidence for the weakening of morphophonological plural marking on the noun head, internally to NPs, in the grammar of some speakers.

2. As far as NPs headed by numerals and indefinite quantifiers are concerned, we noticed they reached high rates of partial agreement (see, for example, the Santomean corpus: on a total of 135 occurrences of partial agreement, 17 involved indefinite quantifiers and 64 a numeral). So, we might say that NPs combined with indefinite quantifiers and numerals behave alike. 
3. In more complex NPs, where two pre-nominal constituents intervene, the left most constituent is the one contributing ${ }^{14}$ to the semantic reading $[+/$ definite/+/specific] and bearing grammatical number information, through $-s$ addition (as suas possibilidade $\varnothing$ 'their possibilities'; uns cem bloco $\varnothing$ 'about one hundred blocks'), although the most frequent pattern for partial agreement is the one with plural marking on the second pre-nominal constituent too. So, the most frequent pattern in partial agreement is for grammatical number to be lexically realized on the pre-nominal constituents, but not on the Noun Head, nor on the post-nominal adjectival modifier.

4. We encountered a substantial number of cases of bare nouns followed by an adjectival modifier; we saw that in these contexts, the noun Head received plural, as noticed by other authors.

5. We also found a significant number of bare nouns with no modifiers and no plural marks, although denoting a plural set of entities. These data are interesting in the sense that it seems that speakers are, in some way, reanalyzing these nouns: they are consequently lexically encoded as plurals and not morphologically marked for agreement. However, when these noun heads (for instance, coisa 'thing') occur with determiners and quantifiers, these constituents in the left periphery are marked for plural.

So, as they are, the agreement patterns we collected, on purely descriptive grounds, basically confirm one of the generalizations made in Scherre (2001b) for BP:

"nominal elements to the left of the nominal head favor overt plural markers, while nominal elements to the right of the nominal head favor zero plural markers. The head itself favors overt plural markers if it is more to the left in the noun phrase; otherwise the head disfavors markers"

\subsection{First steps into understanding the data}

In what follows, we will try to list some questions that, as far as we know, seem to have been less frequently addressed. It should be clear that these observations do not intend to explain the phenomena; they are mere clues for future research.

Notice that in the data presentation for partial agreement patterns, in previous sections, we only comment a quite few syntactic/structural variables, such as the relative linear position of the NP constituents, referring to constituents to the left of the noun head (generically, the specifiers and

14 Although, as an anonymous reviewer accurately points out, other constituents, such as relative sentences, may also contribute to these interpretations. However, these issues are beyond the scope of this paper. 
some pre-nominal quantitative adjectives) and adjectival modifiers, to the right of the Noun Head, and the category they belong to. It seems, indeed, that relative linear order is one of the more significant scalling factors for defective agreement ${ }^{15}$. So the following observations will focus on these variables.

\subsubsection{The functional domain vs lexical domain issue}

- As commonly assumed, the noun specifiers are words with grammatical content. They are usually split into two main classes, determiners (definite and indefinite article, demonstrative), codifying semantic features such as [+/-definite] e [+/-specific] and universal or existential quantifiers, quantizing over entities of different nature $([+/-$ discrete]. In Portuguese, these categories also codify gender ([masculine / feminine]) and number ([singular / plural $]$ ).

- As they codify semantic and grammatical features, the noun specifiers form a grammatical or functional class (containing a finite number of items, without descriptive content; they do not denote entities, properties nor situations). Being so, they built the 'functional domain' of Noun Phrases, while the noun and the post-nominal adjectival modifiers built its 'lexical domain'.

- Numerals are items morphologically invariable (except for um and dois 'one and two', which vary in gender) but, except for um 'one', they are semantic plurals. Let us remind that these occurrences reach a quite high occurrence rate in our sample and showed no plural morpheme on the Noun Head.

15 Brandão, in this volume, presents results that point to the education level as another important factor: informants with higher level of education tend to produce fewer contexts with lack of agreement. However, the difference between the fundamental and the medium level is less significant in terms of percentage. This is in line with our findings in the Nova Iguaçu corpus and this data requires some consideration. In what concerns speakers of the medium level in our sample, one of the informants has only 6 years of education (close to the fundamental level, which accounts for 5 years) and seems indeed closer to the fundamental level in terms of the number of contexts of defective agreement produced in the recorded conversation (35 cases); another speaker explains that he corrected his way of speaking because of his work ( 4 cases of defective agreement) and seems closer to the higher educational level. These two speakers mostly account for the disparity in terms of total percentage for this level, while the remaining ones show a convergent behaviour. So the distribution of contexts with lack of agreement among informants points to a clear tendency for education to be a determinant factor.

In what concerns the African varieties, one also needs to take into consideration the special case of Portuguese as L2 (cf. Jon-And (2011) for a quantitative study of oral corpus from Maputo (Mozambique), and Mindelo (Cape Verde)). 
- Being true that the so called 'adjectival quantifiers' / 'quantitative adjectives' may appear in the left most position inside Noun Phrases (dois filho $\varnothing$ 'two sons'; certos aviso $\varnothing$ 'certain warnings' (MOC_12); muitas coisa $\varnothing$ 'many things' (ANG_01); outras etnia $\varnothing$ 'other ethnical groups' (ANG_04)), so filling the expected position for indefinite quantifiers, it is worth noticing that some of these items may combine internally to a same Noun Phrase, with a definite and /or indefinite article, a possessive and a demonstrative, as we saw above (as outras igreja $\varnothing$ 'the other churches'; nas outras regiões mais distante $\varnothing$ 'in the other regions, more distant' (NIG-C-2-M); meus vinte ano $\varnothing$ 'my twenty years' (NIG-C-2-H); uns vinte minuto $\varnothing$ 'about twenty minutes' (NIG-C-2-H)). Furthermore, considering that the most frequent pattern in the contexts involving two pre-nominal constituents is for both to exhibit plural marking, it seems that the speakers using this pattern are sensitive to the distinction between functional and lexical domain, treating them apart: only the functional domain receives plural marking. This may suggest that, somehow, these speakers process the two constituents as complex determiners.

- As for the lexical domain, including the Noun Head and the post-nominal adjectives, it is unmarked for plural. These two domains seem to have complementary functions, the grammatical information being localized in the constituents without descriptive content (see above).

- We observed that in a few cases, there was no plural morpheme on the second prenominal constituent. Notice that the categorial nature of these constituents is not always clear cut, since they may occur in positions adjacent to the left of the Noun Head, as pure adjectives do (cf. as minhas três outras amigas 'my three other friends'/ as minhas outras três amigas 'my other three friends'). Also, some of these weak adjectives may be treated as belonging to the lexical domain as other adjectival modifiers; if so, the lack of agreement would be expected.

\subsubsection{The bare nouns issue}

It is clear from many works on the distribution of bare singular count noun in BP (cf. Müller (2002), Munn \& Schmitt (2005), Schmitt and Munn ((1999), (2002)), Oliveira \& Rothstein (2011), among many others) that these categories have a wide use; so, the agreement issues we are facing, showing lack of plural marking on the noun head, would have to inquire the possible relation between the two phenomena. 
In Oliveira \& Rothstein (2011: 252) it is assumed that bare singular count nouns ${ }^{16}$ behave as mass nouns and that "there are just two sorts of bare nouns in BrP: Bare Mass nouns and bare plurals".

Furthermore, p. 251-252, the authors claim that "Bare singulars [cf. menino 'boy'] are (...) mass nouns, which are derived alongside the count form of the lexeme. Brazilian Portuguese is a good example of such language. On this account, bare singulars in Brazilian Portuguese denote kind terms (just as other mass nouns do)".

As for the distribution of bare nouns, and the interpretation they bear, Oliveira \& Rothstein (2011:246) sketch the following:

"(i) the $\mathrm{B}($ are $) \mathrm{P}$ (plural) is always ambiguous between kind and existential readings;

(ii) the bare singular and the bare mass always denote the kind;

(iii) only the BP may be the subject of episodic sentences that are not about the kind;

(iv) only the BP is ambiguous between specific and non-specific readings, the bare singular and the bare mass are always non-specific."

Finally, Oliveira \& Rothstein (2011:263) observe that

"(i) contrary to what is taken for granted in the literature, the bare singular is not always bare, it may be bound by mass quantifiers, and

(ii) in comparative sentences, the bare singular behaves as mass, since it does not necessarily access the cardinal scale."

The examples for bare singular nouns bound by mass quantifiers are as illustrated below in (71). The contexts with comparative sentences are those in (72-73), where we may find bare singulars (72a-b) and bare plurals (73a-b). Examples (71)-(73), as well as their explanation and paraphrase, are from Oliveira \& Rothstein (2011:ex (42), (46)-(47)).

(71) a. Quanto livro você acha que pode levar!?

Much book you think that can to carry

Intended meaning: "What quantity of book can you carry?"

b. É muito livro pra você levar.

Is much book for you to carry?

Intended meaning: "The volume of books is too much for you to carry."

(72) a. Esse jardim tem mais pedra do que aquele.

This garden has more stone of +the that other.

"This garden has more stone than the other one."

${ }^{16}$ We refer back to the text for a full comprehension of the hypotheses put forward. 
b. João tem mais corda que Pedro. João has more rope than Pedro.

"João has more rope than Pedro."

(73) a. Esse jardim tem mais pedras do que aquele.

This garden has more stones of + the that other.

"This garden has more stones than the other one."

b. João tem mais cordas que Pedro.

João has more rope that Pedro.

"João has more rope than Pedro."

Although these are open issues of quite complex nature, what seems to matter for the plural agreement phenomena is, first, that bare singulars behave akin mass nouns and, in second place, that they may combine with mass quantifiers, as will be referred in the next point.

\subsubsection{The quantified Noun Phrases issue}

As far as we know, works on partial agreement inside NPs do not use to split apart Definite and indefinite NPs with partial agreement and NPs combined with indefinite quantifiers, but it could be an interesting question to address.

- Not only most indefinite quantifiers may combine with discrete and non discrete entities but, in many cases, as we saw from Oliveira \& Rothstein (2011), a semantic reinterpretation may apply, converting discrete entities into non discrete ones as in (74):

(74) muito turista / muitos turistas; muito livro / muitos livros; muita pedra / muitas pedras; muita mobília / muitas mobílias

"a lot of tourist / many tourists; a lot of book / many books; a lot of stone / many stones; a lot of furniture / many furnitures"

So, in these contexts, the input may be contradictory (see 6.2); it is worth noticing that the semantic reinterpretation issue is an area of variation in EP too: some speakers allow for singulars in this contexts, even in the case of discrete entities, others do not.

- As we saw, in numerals plural is a semantic feature, not exhibited by the plural morpheme. This could be a clue for the lack of plural on the Noun Head they combine with. Speakers treat these cases as a semantic plural feature; nor the numeral, nor the noun head receive plural morpheme.

So, summarizing the issues covered in section 6 , the data suggest that for the speakers whose grammar display partial agreement, there appears to exist a clear cut between functional domain and lexical domain: the first one is bearing grammatical information and stating discourse anchoring ([+/-anaphoric]; [+/-specific]; [+/-definite; [+/- quantified]; the second one 
seems to denote entities, with some kind of semantic sub-specification for the [mass /kind term] features whose default marking is the singular form and, independently from the kind of determiner in the noun phrase, the speakers do not commit themselves with the [-mass /-kind term] semantic features of the noun head (but see footnote (4) for the idea of a possible phonological explanation on the weakening of grammatical plural number on the noun head).

Finally, it should be clear from the observations about bare singulars that this is a critical area internally to Portuguese, independent from the variety we are describing, involving semantic issues; if so, this variation would be allowed by internal properties of this language grammar.

Based on the previous observations, we may try to translate in Table 9 the above remarks in terms of some features of grammar parameters setting, for the varieties sample we observed, that would require an in-depth analysis, since these would only apply for count nouns:

Table 9: Grammar parameters setting for defective number agreement in the Portuguese varieties

(a) EP

(i) In the constituents left to the noun head, plural

[yes] grammatical number has morphological and semantic content

(ii)

a. In the noun head, plural grammatical number has semantic content

[yes]

b. In the noun head, plural grammatical number has

[yes] morphological content

(iii) a. In the adjectival constituents at the right of the noun head, plural grammatical number has semantic content

[yes]

b. In the adjectival constituents at right periphery of the

[yes] noun head, plural grammatical number displays agreement features for number

(iv) Nouns with the feature $[+$ count $]$ may be re-categorized as [-count] 
(b) PB-Nova Iguaçu and African varieties (informal registers)

\begin{tabular}{llr}
\hline (i) & $\begin{array}{l}\text { In the constituents left of the noun head, plural } \\
\text { grammatical number has morphological and semantic } \\
\text { content }\end{array}$ & [yes] \\
\hline (ii) & $\begin{array}{l}\text { a. In the noun head, plural grammatical number has } \\
\text { semantic content }\end{array}$ & [yes] \\
\hline & $\begin{array}{l}\text { b. In the noun head, plural grammatical number has } \\
\text { morphological content }\end{array}$ & [yes] \\
\hline (iii) & $\begin{array}{l}\text { a. In the adjectival constituents at right periphery of the } \\
\text { noun head, plural grammatical number has semantic } \\
\text { content }\end{array}$ & $\begin{array}{l}\text { b. In the adjectival constituents at right periphery of the } \\
\text { noun head, plural grammatical number displays } \\
\text { agreement features for number }\end{array}$ \\
\hline (iv) & $\begin{array}{l}\text { Only functional categories display the lexically realized } \\
\text { plural morpheme }\end{array}$ & [yes] \\
\hline (v) & $\begin{array}{l}\text { The feature [+/- count] is neutralized on the noun head } \\
\text { [yes] / [-] }\end{array}$
\end{tabular}

\section{Final remarks}

This study, focusing on agreement inside NPs, especially agreement between Head Noun and constituents with adjectival function, has allowed us to establish some patterns concerning number and gender agreement in BP and in the African varieties of Portuguese. Our results point to patterns where left and right periphery of the noun behave differently regarding agreement in number. It also suggests that speakers distinguish between functional and lexical domain in what concerns agreement. A detailed analysis of the different types of determiners and quantifiers occurring in the left periphery points to the fact that position is not the sole factor, but must be considered together with the function carried out by each of the noun specifiers: only the functional domain appears to be marked for plural, although the border line for each domain does not always seem clearly established. Another important factor raised by our data, and that needs to be further investigated, is the frequent use of bare singular nouns which might be interpreted in these contexts as kind terms and its effect in number agreement inside the NP.

The data that we have encountered in the corpora point to a scalar organization of the different varieties in relation to the lack of number agreement: categorical agreement in $\mathrm{EP}$, a large number of cases of defective 
agreement in the African varieties, following essentially the same patterns as $\mathrm{BP}$, and an expressive number of defective number agreement in BP.

\section{References}

Bacelar do Nascimento, M. F., Pereira, L., Bettencourt Gonçalves, J., Estrela, A., Pereira, A., Santos, R., Oliveira, S. (2007) As variedades africanas do português: um corpus comparável. In X Simposio Internacional de Comunicación Social. Ministerio de Ciencia, Tecnología y Medio Ambiente, v. I, Janeiro, Santiago de Cuba.

Brandão, S. F. \& Vieira, S. R. (Orgs.) (2007) Ensino de gramática: descrição e uso, 1. São Paulo: Contexto.

Brandão, S. F. \& Vieira, S. R. (2012) A concordância nominal verbal no Português do Brasil e no Português de São Tomé: uma abordagem sociolinguística. Papia: Revista Brasileira de Estudos Crioulos e Similares, 22(1), 7-39.

Brito, A. M. (2001) Presença / ausência de artigo antes de possessivo no Português do Brasil. In Actas do XVI Encontro Nacional da Associação Portuguesa de Linguística, pp. 551-575. Lisboa: APL.

Castro, A. (2001) Os Possessivos em Português Europeu e Português Brasileiro unidade e diversidade. In Actas do XVI Encontro Nacional da Associação Portuguesa de Linguística, pp. 599-613. Lisboa: APL.

Costa, J. \& Figueiredo Silva, M. C. (2006) Notas sobre a concordância verbal e nominal em português, Estudos Linguísticos, XXXV, 95-109.

Figueiredo, C. F. G. (2008) A concordância variável no sintagma nominal plural do Português reestruturado de Almoxarife (São Tomé), PAPIA, 18, 23-43.

Galves, C. M. C. (1993) O enfraquecimento da concordância no português brasileiro. In Português brasileiro: uma viagem diacrônica (M. A. Kato \& I. Roberts, editors), pp. 387-403. Campinas: Editora da UNICAMP.

Gonçalves, P. (1990) A Construção de uma Gramática do Português em Moçambique: Aspectos da Estrutura Argumental dos Verbos. Dissertação de doutoramento, Lisboa: Universidade de Lisboa.

Gonçalves, P. \& Stroud, C. (eds.) (1998) Panorama do Português Oral de Maputo, Vol. 3 - Estruturas Gramaticais do Português: Problemas e Exercícios, Cadernos de Pesquisa $n^{\circ} 27$. Maputo: INDE.

Inverno, L. (2004) Português vernáculo do Brasil e Português vernáculo de Angola: reestruturação parcial vs. mudança linguística. In Los Criollos de base ibérica (M. Fernández, M. Fernández-Ferreiro \& N. Vázquez Veiga, editors), pp. 201-213. Madrid: Iberoamericana/Frankfurt am Main: Vervuert.

Jon-And, A. (2011) Variação, contato e mudança linguística em Moçambique e Cabo Verde. PhD Dissertation, Stockholm University, Dept. of Spanish, Portuguese and Latin American Studies (http://www.catedraportugues.uem.mz/? target_=lista-bibliografia). Accessed on May 20, 2013.

Jon-And, A. (2010) Concordância variável de número no SN no português L2 de Moçambique - algumas explicações sociais e linguísticas, Revista de Crioulos de Base Lexical Portuguesa e Espanhola, 2 (2010), 28-50.

Krifka, M., Pelletier, F. J., Carlson, G.N., Meulen, A. Ter, Chierchia, G., Link, G. (1995) Genericity: An introduction. In The Generic Book (Carlson, G.N \& 
Pelletier, F.J., editors), pp. 1-124. Chicago and London: The University of Chicago Press.

Magalhães, T. M. V. (2004) A valoração de traços de concordância dentro do DP, DELTA, 20(1), 149-170.

Miguel, M. (2002) Possessive pronouns in European Portuguese and Old French, Journal of Portuguese Linguistics, 2, 214-240.

Miguel, M. (2004) O Sintagma Nominal em Português Europeu: Posições de sujeito. Dissertação de Doutoramento, Universidade de Lisboa.

Miguel, M., Mendes, A., Mota, M.A. (2012) Fenómenos de concordância em variedades do português: construções com verbos copulativos e com verbos transitivos predicativos. In La lengua, lugar de encuentro, Actas del XVI Congresso Internacional de la ALFAL (A. M. Cestero Mancera, I. Molina Martos, F. Paredes Garcia, editors). Alcalá de Henares, June 6-9 2011.

Müller, A. P. (2002) The Semantics of Generic Quantification in Brazilian Portuguese, Probus, 14, 279-298.

Müller, A. L.P. (1997) A gramatica das formas possessivas no português do Brasil. Dissertação de Doutoramento, Universidade Estadual de Campinas, Instituto de Estudos da Linguagem

Müller, A. L. de P., Negrão, E. V., Quadros Gomes, A.P. (2007) “Todo” em contextos coletivos e distributivos, DELTA, 23(1), 71-95.

Munn, A. \& Schmitt, C. (2005) Number and Indefinites, Língua, 115, 821-855.

Naro, A. \& Scherre, M. M. P. ( 2003) Estabilidade e mudança linguística em tempo real: a concordância de número. In Mudança linguística em tempo real (M. C. Paiva \& M. E. L. Duarte, organizers), pp. 47-62. Rio de Janeiro: Contra Capa.

Naro, A. J. \& Scherre, M. M. P. (2007) Origens do português brasileiro. São Paulo: Parábola.

Oliveira, R. P. \& Rothstein, S. (2011) Two Sorts of Bare Nouns in Brazilian Portuguese. Revista da ABRALIN, special number, 1 a parte 2011, 231-266.

Rinke, E. (2010) A combinação de artigo definido e pronome possessivo na história do português, Estudos de lingüistica galega, 2(2010), 121-139.

Ritter, E. (1991) Two functional categories in noun phrases: evidence from Modern Hebrew. In Syntax and semantics 25: perspectives on phrase structure (S. Rothstein, editor). New York: Academic Press.

Ritter, E. (1993) Where's gender?, Linguistic Inquiry, 24, 795-803

Rodrigues, E. S. (2006) O processamento da concordância de número entre sujeito e verbo na produção de sentenças. Tese de Doutoramento, Pontifícia Universidade Católica do Rio de Janeiro, Rio de Janeiro.

Scherre, M. M. P. (1991) A concordância de número nos predicativos e nos particípios passivos, Organon - A variação no português do Brasil, 18(5), 52-70.

Scherre, M. M. P. (1994) Aspectos da concordância de número no português do Brasil, Revista Internacional de Lingua Portuguesa (RILP) - Norma e Variação do Português, 12, 37-49.

Scherre, M. M. P. (2001a) Major linguistic patterns in noun phrase agreement in Brazilian Portuguese. Cinquanta'anni di recerche linguistiche: problemi, resultati e prospettive per il terzo millennio. Atti del IX convegno internazionale di linguisti - tenuto a Milano nei giorni 8-18 ottobre 1998, pp.461-473. 
Alessandria: Edizioni dell'Orso S.r.l. Sodalizio Glottologico Milanese - Instituto Lombardo - Academia di Scienze e Leterre.

Scherre, M. M. P. (2001b) Phrase-level parallelism effect on noun phrase number agreement, Language Variation and Change, 13(2001), 91-107.

Scherre, M. M. P.; Naro, A. J. \& Rodrigues Cardoso, C. (1998) Sobre a concordância de número no português falado do Brasil. In Dialettologia, geolinguistica, sociolinguistica. Atti del XXI Congresso Internazionale di Linguistica e Filologia Romanza, Centro di Studi Filologici e Linguistici Siciliani, Universitá di Palermo (G. Ruffino, organizer), pp. 509-523. Tübingen: Max Niemeyer Verlag, 5.

Scherre, M. M. P., Naro, A. J., Rodrigues Cardoso, C. (2007) O Papel do tipo de verbo na concordância verbal no Português Brasileiro, D.E.L.T.A, 23, 283-317.

Schmitt, C. \& Munn, A. (1999) Against the Nominal Mapping Parameter: Bare nouns in Brazilian Portuguese. In Proceedings of NELS 29.

Schmitt, C. and Munn, A. (2002) The syntax and semantics of bare arguments in Brazilian Portuguese, Linguistic Variation Yearbook, 2, 185-216.

Silva, T. C.; Almeida, L. \& Guedri, C. (2007) Perda da marca de plural no português brasileiro: contribuições da Fonologia, Estudos da Linguagem, 15(2), 207-228.

Simioni, L. A. (2007) A concordância de número no DP: propostas minimalistas, Estudos Lingüísticos, XXXVI(1), 117-125.

Tavares da Silva, J. C. T. (2011) Variação no processo de concordância nominal: estudo comparativo das décadas de 70 e 90, Revista Icarahy, 5. http://www.revistaicarahy.uff.br/revista/html/numeros/5/dlingua/JOAO_CARLOS .pdf. accessed on May 20, 2013.

Tenório, T. S. (2008) A Concordância de número e de gênero entre o DP pronominal a gente e o predicativo: uma comparação entre o português brasileiro e o português europeu. Universidade Federal de Alagoas.

Matilde Miguel

Faculdade de Letras da Universidade de Lisboa Centro de Linguística da Univ. de Lisboa tilde@mail.telepac.pt
Amália Mendes

Faculdade de Letras da Universidade de Lisboa Centro de Linguística da Univ. de Lisboa amalia.mendes@clul.ul.pt 